\title{
Urban Environmental Health Hazards and Health Equity
}

Tord Kjellstrom, Sharon Friel, Jane Dixon, Carlos Corvalan, Eva Rehfuess, Diarmid Campbell-Lendrum, Fiona Gore, and Jamie Bartram

\begin{abstract}
This paper outlines briefly how the living environment can affect health. It explains the links between social and environmental determinants of health in urban settings. Interventions to improve health equity through the environment include actions and policies that deal with proximal risk factors in deprived urban areas, such as safe drinking water supply, reduced air pollution from household cooking and heating as well as from vehicles and industry, reduced traffic injury hazards and noise, improved working environment, and reduced heat stress because of global climate change. The urban environment involves health hazards with an inequitable distribution of exposures and vulnerabilities, but it also involves opportunities for implementing interventions for health equity. The high population density in many poor urban areas means that interventions at a small scale level can assist many people, and existing infrastructure can sometimes be upgraded to meet health demands. Interventions at higher policy levels that will create more sustainable and equitable living conditions and environments include improved city planning and policies that take health aspects into account in every sector. Health equity also implies policies and actions that improve the global living environment, for instance, limiting greenhouse gas emissions. In a global equity perspective, improving the living environment and health of the poor in developing country cities requires actions to be taken in the most affluent urban areas of the world. This includes making financial and technical resources available from high-income countries to be applied in low-income countries for urgent interventions for health equity. This is an abbreviated version of a paper on "Improving the living environment" prepared for the World Health Organization Commission on Social Determinants of Health, Knowledge Network on Urban Settings.
\end{abstract}

KEYWORDS Economic resources, Environment, Equity, Social determinants, Urban bealth

\section{INTRODUCTION}

When humans started to live in large numbers in close proximity to each other approximately 5,000 years ago, health challenges included the import of water, food and other essentials to the population, and transport of excreta and other waste products away from the population. Many million people in low-income and

Kjellstrom is with the National Institute of Public Health, Ostersund, Sweden; Kjellstrom and Dixon are with the National Centre for Epidemiology and Population Health, Australian National University, Canberra, Australia; Kjellstrom is with the Health and Environment International Trust, Mapua, Nelson, New Zealand; Friel is with the University College London, London, UK; Corvalan, Rehfuess, CampbellLendrum, Gore and Bartram are with the Department of Public Health and Environment, World Health Organization, Geneva, Switzerland.

Correspondence: Tord Kjellstrom, Health and Environment International Trust, Mapua, Nelson, New Zealand. (E-mail: kjellstromt@yahoo.com) 
informal settlements ("slums") in cities of our own era face similar health challenges. ${ }^{1,2}$ As most of the urban slum dwellers live in tropical countries, their health is also threatened by a variety of tropical diseases influenced by social and environmental determinants. ${ }^{3}$ Health equity can only be achieved by "leveling up" living conditions for the poor ${ }^{4}$ and by reducing differential exposure and vulnerabilities among different groups in society.

People are exposed to a whole variety of factors that can either promote good health or be hazardous to health, including the physical living environment. Modern cities can improve health via their material, service-provision, cultural, and aesthetic attributes..$^{5}$ They also offer opportunities for cost-effective interventions that can serve many people even if carried out on a small scale. Existing healthpromoting infrastructure (e.g., drains and distribution networks for kerosene for cooking) can, in some situations, be upgraded to meet the local health demands. Health hazards and inequities remain, however, and new threats have emerged, but the knowledge and technologies for creating a healthy city are available. ${ }^{6}$

It has been pointed out by $\operatorname{Sen}^{7}$ and Kawachi and Wamala ${ }^{8}$ that poverty is not only a question of money, but it has four other dimensions: lack of opportunities (for employment and access to productive resources), lack of capabilities (access to education, health, and other public services), lack of security (vulnerability to economic risks and violence), and lack of empowerment (absence of voice, power, and participation). This paper suggests adding a fifth dimension: lack of a bealthsupporting physical living environment. These five dimensions stem from inequality as the root causes of poverty.

\section{SOCIAL DETERMINANTS AS DRIVING FORCES BEHIND ENVIRONMENTAL DETERMINANTS}

Social determinants often cause their health effects via webs or pathways of environmental exposures. A framework to describe such pathways (the Driving Forces-Pressures-State-Exposure-Effects-Action [DPSEEA] framework) was developed at World Health Organization (WHO). ${ }^{9,10}$ The social determinant driving forces lead to pressures on the environment that change the state of the environment, which create exposures that cause health effects (Table 1).

The DPSEEA framework is intended to visualize pathways or causal webs for how policies and actions at driving force level are linked to more proximal exposures and finally the health effects. For example, urban people with low incomes and those affected by social discrimination are likely to end up living in "slum" conditions with an unhealthy living environment and exposure to pathogens and disease vectors. Lack of research on many of these interlinkages is an obstacle to quantitative impact analysis of the higher level interventions. The development of environmental burden of disease estimates by $\mathrm{WHO}^{11}$ for different hazards at different levels in the DPSEEA cause-effect framework, and analysis of the environmental health risks in vulnerable groups, such as the Children's Environmental Health analysis, ${ }^{12-14}$ are starting to fill the gaps.

\section{MAJOR ENVIRONMENTAL HEALTH CHALLENGES IN DEPRIVED URBAN AREAS}

Diarrhea, worm infections, and other infectious diseases spread via contaminated water $^{15,16}$ and lack of water creates difficulties for families to carry out basic 


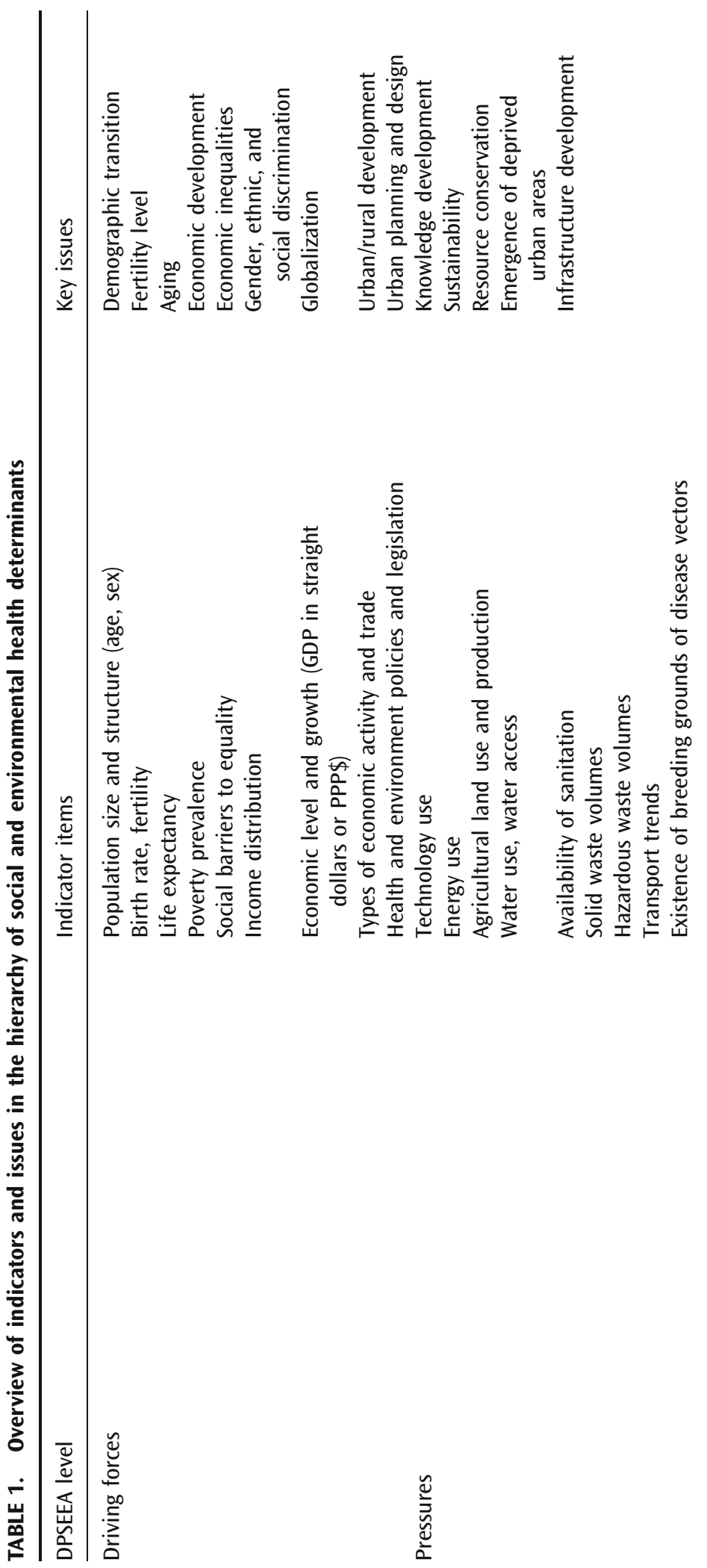



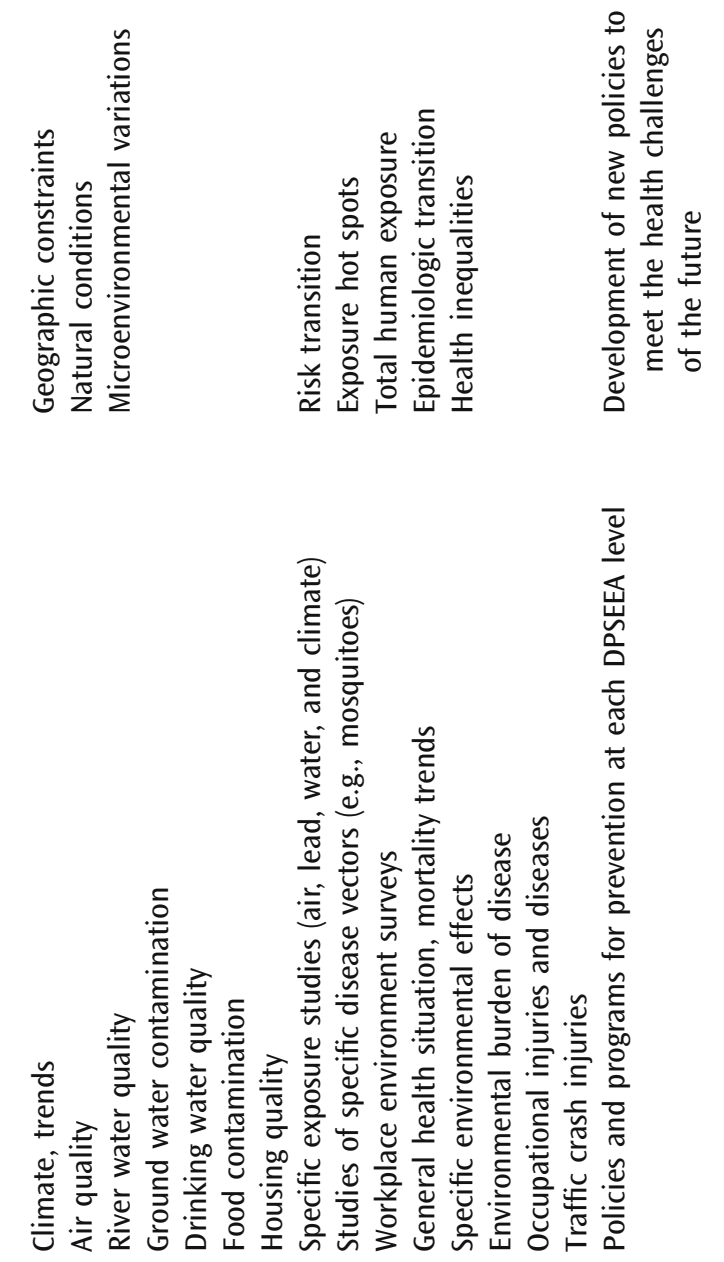

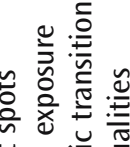

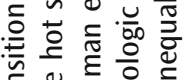
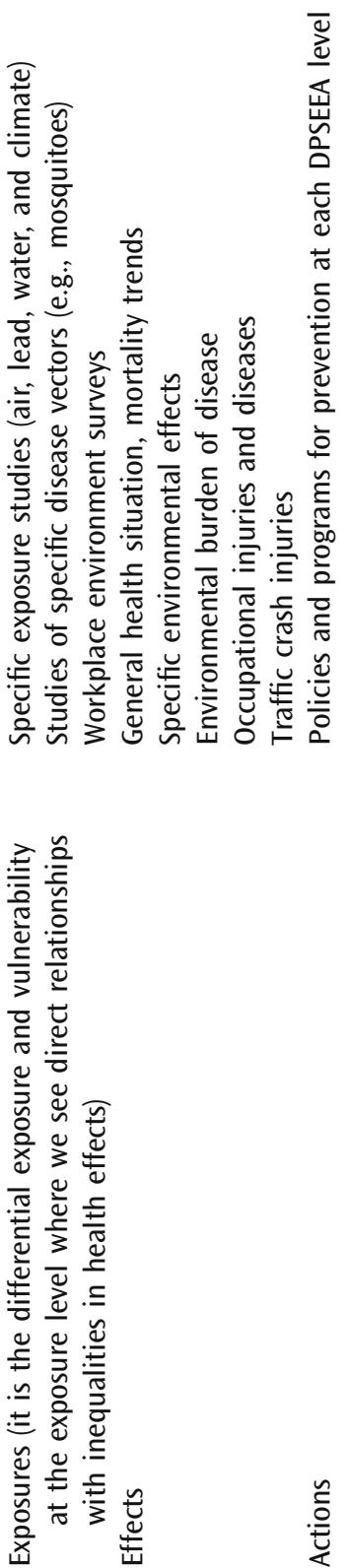
hygiene around the home. Almost half of the urban population in Africa, Asia, and Latin America is suffering from these diseases because of lack of access to improved water and sanitation. ${ }^{2}$ In addition, lack of access to water means hours wasted carrying water from far away or substantial amount of scarce household resources spent on essential human needs. It is mainly women and girls that end up responsible for these chores. ${ }^{15}$

Proper sanitation is just as important for health. ${ }^{15}$ Women and girls are again vulnerable as many of them, for reasons of culture and modesty, will not attend to their sanitary needs during daylight hours if required to use a communal latrine. In $200251 \%$ of populations in developing countries still lacked proper sanitation whereas $21 \%$ lacked safe and sufficient drinking water. ${ }^{15}$ In urban areas the coverage is higher, but most people in slums have inadequate facilities. Exposure to disease vectors, including mosquitoes, because of lack of liquid or solid waste management is an increasing health threat in these areas.

More than three billion people depend on solid fuels, including biomass (wood, dung, and agricultural residues) and coal to meet their most basic energy needs: cooking, boiling water, and heating. ${ }^{17}$ A study in Thailand showed a very strong social gradient for fuel use: low-income families use fuel-wood and higher income families use LPG or charcoal. ${ }^{18}$ In urban areas, inequalities are particularly stark: for example, more than $90 \%$ of urban Bangladeshis in the poorest income quintile cook with solid fuels, compared with less than $25 \%$ among the richest quintile. ${ }^{19}$ Burning solid fuels produces high levels of indoor air pollution: typical 24-h levels of $\mathrm{PM}_{10}$ in biomass-using homes range from 300 to $3,000 \mu \mathrm{g} / \mathrm{m}^{3} .^{20}$ By comparison, the WHO air quality guidelines recommend a limit for daily average $\mathrm{PM}_{10}$ is $50 \mu \mathrm{g} / \mathrm{m}^{3}$. $^{21}$

Indoor smoke exposure doubles the risk of child pneumonia and other acute respiratory infections. ${ }^{20}$ It can also increase chronic obstructive pulmonary diseases in women, and double the risk of lung cancer if the smoke comes from use of coal for cooking. ${ }^{20}$

Deprived urban areas often contain workplaces with health hazards because of toxic products, injury and ergonomic hazards, noise, external pollution, and traffic generation. ${ }^{22,23}$ The problems in "cottage industries" are increased because of inappropriate zoning, town planning, and location of industrial activities. ${ }^{24}$ The mix of workplaces and settlements increase the health risks when major industrial accidents occur, as in Bhopal, India, in 1984. ${ }^{25}$ Some serious workplace hazards that have been common in developed countries in the past have now been transferred to developing countries. ${ }^{26}$ Work injuries and poor health because of work hazard exposures lead in themselves to poverty: a vicious circle.

\section{HEALTH EQUITY ISSUES RELATED TO THE MODERN LIVING ENVIRONMENT IN URBAN AREAS}

Epidemiological studies have documented increased morbidity and mortality from motor vehicle air pollution, and poor people often live in the most exposed areas. ${ }^{27}$ In Bangkok as much as $29 \%$ of all cardiovascular disease deaths may be because of current air pollution. ${ }^{28}$ In children and young people injuries related to motor vehicle traffic are among the most common causes of death ${ }^{29}$ and the problem is rapidly increasing in developing countries contributing to health inequity. ${ }^{30}$

The contemporary use of the private motor vehicle is associated with another health threat in urban areas: the obesity epidemic. Walking and bicycling as a 
natural part of daily transport has diminished and lack of daily physical activity contributes to increasing body weight in many populations. Cars are also implicated in changing dietary patterns with increasing consumption of high-energy and high-fat "fast foods." 31 Major visible economic inequalities within cities contribute to social tensions, and pervasive fear of crime which further limits outdoor physical activities. ${ }^{6}$

Whereas water- and food-borne infections because of poor sanitation and inadequate hygiene have receded, emerging respiratory infections (e.g., SARS and avian influenza) retain the potential for rapid spread in areas with high population density. Other hazards in urban areas are lead in paint on houses and use of asbestos-cement building products. ${ }^{24}$

Cities require constant energy and resource inputs, as well constant waste disposal to be able to sustain human life. ${ }^{32}$ To achieve sustainability modern cities need to be planned and managed with these resource and waste issues in mind. An important contemporary resource depletion issue is global climate change. ${ }^{33,34}$ Cities contribute to climate change through their large energy demands. The health effects of a warming world are likely to be overwhelmingly negative, ${ }^{35}$ particularly in the poorest communities, which have contributed least to greenhouse gas emissions. $^{36}$ Some health effects may affect rural people more than urban people (e.g., effects of reduced local food production) whereas other effects are more prominent in cities. For instance, the effects of heat waves are exacerbated by the urban "heat island" effect. ${ }^{37}$ The excess mortality in Europe in $2003^{38,39}$ was more than 40,000 people (mainly elderly low-income people. ${ }^{40}$ Whereas the effects in temperate regions may be partly compensated by lower winter mortality and adaptation $^{41}$, tropical cities do not experience such compensation. ${ }^{42}$

Sea level rise, more violent tropical cyclones and river floods, water- and foodborne gastrointestinal infections, and vector-borne diseases (e.g., dengue fever ${ }^{43}$ ) are other health risks of the urban poor because of climate change. ${ }^{35}$

Levels of air pollutants, such as ozone, because of motor vehicle emissions tend to be higher on warmer days. Ozone-related deaths may increase by $\sim 4.5 \%$ because of climate change by the 2050 s. ${ }^{44}$ This is likely to affect millions of people in urban populations across the world. ${ }^{45}$ Half of the 15,000 additional deaths during the 2003 heat wave in France may have been because of increased ozone levels associated with the high temperatures. ${ }^{46}$

Urbanization also involves a shift in consumption from wild game meat or small landholder/householder reared poultry and pork to industrially reared beef, pork, and chickens. This has happened in less than 50 years and has numerous environmental consequences, ${ }^{31,47-49}$ e.g., land-clearing; extensive use of fertilizers, pesticides, and water; the recycling of feathers, carcass, and waste; and use of veterinary antibiotics and large numbers of livestock that contribute to methane production, a more potent greenhouse gas than carbon dioxide. Urbanization limits possibilities for household food production and contributes to environmental damage through long distance food transportation (greenhouse gases etc.) ${ }^{50}$

\section{COMPREHENSIVE APPROACHES TO ACHIEVING EQUITABLE ENVIRONMENTAL HEALTH CONDITIONS}

The Millennium Development Goal target number 11 states: "have achieved by 2020 a significant improvement in the lives of at least 100 million slum dwellers." This is a very modest target (less than $10 \%$ of dwellers) as there is already one 
billion people living in slums and the number is increasing. "Slum upgrading" offers an opportunity for rapid scale-up of concrete action ${ }^{1}$ in a cost-effective manner. ${ }^{51}$ It consists of improving security of tenure (often through regularization of land rights) and improving the basic services provision (e.g., water services, energy for cooking and lighting, storm water drainage systems, and security lighting) and housing, mitigation of environmental hazards, provision of incentives for community management, improving access to health care and education, and enhancement of livelihoods through training and microcredit. ${ }^{52,53}$

Improved water supply should be combined with improved sanitation ${ }^{54,55}$ and a separate toilet in each household to facilitate personal hygiene, particularly for women and girls. These interventions are highlighted in the Millennium Development Goals target number 10: "Halve, by 2015, the proportion of people without sustainable access to safe drinking water and basic sanitation." When water resources are severely restricted alternatives to water-borne sewerage would be the best solution. ${ }^{56}$ Other interventions include clean fuels and efficient stoves, liquid and solid waste management, and improved housing. ${ }^{2}$ The cost can be surprisingly low (US \$500 per household ${ }^{57}$ ), if the slum upgrading is carried out with active community participation.

Another approach is to build whole new housing areas with all the necessary facilities available from the beginning. If it is done in a way that takes into account the fears and desires of the poor, as was done in Singapore several decades ago ${ }^{58}$, it can be very successful.

A comprehensive approach that combines infrastructure improvement, health promotion, and community participation is the Health City, Municipality and Settings approach promoted by WHO and Pan-American Health Organization for many years (see WHO websites for references). It engages local governments in health development through a process of political commitment, institutional change, capacity building, partnership-based planning, and innovative projects. ${ }^{59,60}$ It promotes comprehensive and systematic policy and planning with an emphasis on health inequalities and urban poverty. There are now several thousand "healthy cities" linked through national, regional, metropolitan, and thematic networks.

\section{INTERVENTIONS FOR ENERGY, TRANSPORT, AND INDUSTRY}

Switching from wood, dung, or charcoal to more efficient modern fuels, such as kerosene, LPG, and biogas, brings about the largest reductions in indoor smoke ${ }^{61}$. In many poor urban communities, however, biomass remains the most practical fuel and there, improved stoves can cut back indoor smoke levels and fuel use considerably, which improves health and reduces energy costs. ${ }^{19}$

There is a wide range of technological and planning options that supply alternatives to the private motor vehicle for people's mobility needs. For example, the proportion of people walking or cycling to work varies from $32 \%$ in Copenhagen, to $22 \%$ in Tokyo, and to $0.3 \%$ in Atlanta. Values in developing countries are equally variable, from $30 \%$ in Santiago to $2 \%$ in Brasilia. ${ }^{62}$ The rapid development of the physical size of cities and town planning promoting "sprawl" and a global "car culture" add to the health concerns of private motor vehicle transport. ${ }^{63,64}$ Improved public transport, planning for "walkability," and a reduction of "unnecessary" private motor vehicle travel are essential to create a healthy environment in cities. ${ }^{65}$ 
Studies of the benefits and monetary costs of major air pollution control efforts $^{27}$ have concluded that the benefits, at least in developed countries, far outweigh the costs. Policies and actions to control air pollution from vehicles and industry can be important interventions for health equity. In general, measures aimed at the reduction of air pollution and hence the exposure of millions of urban dwellers will also decrease greenhouse gas emissions and vice versa. ${ }^{33}$

\section{WORKPLACE HAZARD INTERVENTIONS}

Numerous reports describe prevention methods for specific hazards (lead, asbestos, organic solvents, silica dust, accidents/injuries, etc.), including materials from the occupational health and safety programs of WHO and International Labor Organization (ILO). ${ }^{23}$ Interventions concerning these hazards improve health equity because low-income people generally end up working in jobs in the unprotected informal sector with the greatest health risks. ${ }^{26}$

The ILO develops conventions and guidelines to improve occupational health and safety. An important intervention at the local urban level is the labor inspectorate $^{66}$ that needs to be appropriately resourced. Trade unions are natural partners for awareness raising and local action, as well as for promotion at government level of healthy work policies and legislation.

\section{RESOURCES FOR HEALTH EQUITY INVESTMENTS}

In the early 1970s the UN General Assembly recommended that high-income countries should provide $0.7 \%$ of their GDP to development aid and this was later reiterated in other fora, including the Rio Summit in 1992. The level never reached more than $0.36 \%$ or US $\$ 90$ billion. ${ }^{67}$ The accumulated shortfall of aid since 1975 is about US $\$ 2$ trillion (calculated by Kjellstrom, unpublished data), which could be seen as a debt from the rich to the poor. The annual gross world product is US $\$ 40$ trillion, two thirds of which is created in the high-income countries. Aid at $0.7 \%$ of GDP would amount to US $\$ 180$ billion per year.

According to an analysis by Sachs, ${ }^{68}$ aid needs to be doubled to achieve the Millennium Development Goals and other global equity aims. One way to collect additional resources for aid would be a small tax on foreign exchange transactions, the so-called Tobin tax (after the economist James Tobin, who suggested this more than 25 years ago). This tax was meant to discourage speculative foreign exchange transactions while the influence on long-term cross-border trade and investments would be minimal. ${ }^{69}$ Approximately US \$2 trillion in foreign exchange transactions are carried out each day. ${ }^{70} \mathrm{~A}$ superficial estimate indicates that a Tobin tax of $0.02 \%$ would collect US \$400 million per day, or US \$150 billion per year, similar to the aid commitment made by the high-income countries in the 1970s. However, a detailed analysis is required to make a more reliable estimate.

Low- and middle-income countries are not likely in the near future to be able to provide all the funds needed to create a truly healthy living environment. Funding from the more affluent countries will be required to back up the plans made by peoples and governments in the less affluent countries. ${ }^{68}$ An equitable sharing of wealth and resources globally is the greatest inequity challenge facing the world. ${ }^{71}$ 


\section{CONCLUSIONS, KEY MESSAGES}

- Clean and sufficient drinking water, proper sanitation and drains for waste water, and proper solid waste management are the key health equity interventions in deprived urban areas, and cost-effective solutions exist.

- Household energy supply is a major environmental health issue because of the harmful effects of biomass and coal smoke. Alternative fuels for cooking and heating need to be made available and electricity for lighting and refrigerators provides great benefits for health.

- The working environment can be harmful to health of the poor and powerless. Specific interventions exist for all types of industrial activity, including cottage industries.

- Availability of and access to public transport is a key element in improving transport "equity" and reducing the negative health impacts of a "car society."

- Providing food for the growing urban populations has its own environmental and health risks. Interventions to create a sustainable food supply based on principles of resource conservation and environmental protection is a key issue for future health equity.

- Broad environmental health policies, such as those promoted by the Healthy Cities and Municipalities movement, provide excellent frameworks for improving the living environment and health for poor people

- Global climate change is likely to particularly affect health of poor people in both rural and urban areas. Actions to reduce its severity are therefore actions for health equity.

- A timely improvement in the living environment for all deprived and disadvantaged people is necessary for health equity and this will require greater transfer of financial and technical resources from the affluent to the less affluent.

\section{ACKNOWLEDGEMENTS}

This work was made possible through funding provided by the WHO and undertaken as work for the Knowledge Network for Urban Settings established as part of the WHO Commission on the Social Determinants of Health. Some authors are staff members of the WHO. The views presented in this report are those of the authors and do not necessarily reflect the decisions, policies, or views of WHO or the Commissioners.

\section{REFERENCE}

1. UN Habitat. The Challenge of Slums: Global Report on Human Settlements. Nairobi, Kenya, UN: Habitat; 2003.

2. Garau P, Sclar ED, Carolini GY. A Home in the City. Report from the UN Millennium Project. London: Earthscan Publ.; 2005.

3. Utzinger J, Keiser J. Urbanization and tropical health-then and now. Ann Trop Med Parasitol. 2006;100:517-533. 
4. Dahlgren G, Whitehead M. Levelling Up: Strategies for Tackling Social Inequalities in Health. Venice, Italy: WHO-EURO Office for Investment for Health and Development; 2006.

5. Kirdar U. Cities Fit for People. New York: UNDP; 1997.

6. Galea S, Vlahov D. Handbook of Urban Health. New York: Springer; 2005.

7. Sen A. Development as Freedom. New York: Alfred A Knopf Publ.; 1999.

8. Kawachi I, Wamala S. Globalization and Health. New York: Oxford University Press; 2007.

9. Kjellstrom, T, Corvalan, C. Framework for the development of environmental health indicators. World Health Stat Q. 1995;48:144-154.

10. Corvalan C, Briggs D, Kjellstrom T. Development of environmental health indicators. In: Briggs D, Corvalan C, Nurminen M, eds. Linkage Methods for Environment and Health Analysis. Geneva: World Health Organization; 1996:19-54.

11. Prüss-Üstün A, Carlos Corvalán C. How much disease burden can be prevented by environmental interventions? Epidemiology. 2007;18:167-178.

12. WHO. Making a Difference: Indicators to Improve Children's Environmental Health. Geneva: World Health Organization; 2003.

13. WHO. From Theory to Action: Implementing the WSSD Global Initiative on Children's Environmental Health Indicators. Geneva: World Health Organization; 2004.

14. Commission for Environmental Cooperation. Children's Health and the Environment in North America. Montreal: Commission for Environmental Cooperation (produced in collaboration with PAHO); 2006.

15. WHO. Water for Life. Joint WHO and UNICEF Publication. Geneva: World Health Organization; 2005.

16. WHO. Guidelines for Drinking Water Quality. 3rd Edition. Geneva: World Health Organization; 2006.

17. Rehfuess E, Mehta S, Prüss-Üstün A. Assessing household solid fuel use-multiple implications for the millennium development goals. Environ Health Perspect. 2006;114:373-378.

18. Friel S, McMichael AJ, Kjellstrom T, Prapamontol T. Housing and health transition in Thailand. Rev Environ Health. 2004;19:311-327.

19. Rehfuess E. Fuel for Life: Household Energy and Health. Geneva: World Health Organization; 2006.

20. Smith KR, Mehta S, Feuz M. Indoor air pollution from household use of solid fuels. In: Ezzati M et al., eds. Comparative Quantification of Health Risks: Global and Regional Burden of Disease Attributable to Selected Major Risk Factors. Geneva: World Health Organization; 2004.

21. WHO. Air Quality Guidelines for Particulate Matter, Ozone, Nitrogen Dioxide and Sulfur Dioxide_Global Update 2005. Geneva: World Health Organization; 2006.

22. Levy BS, Wegman DH. Occupational Health. Boston: Little, Brown and Co; 1988.

23. Stellman J. ed. ILO Encyclopaedia on Occupational Safety and Health. Geneva: International Labour Office; 1998

24. Yassi A, Kjellstrom T, de Kok T, Guidotti TL. Basic Environmental Health. New York: Oxford University Press; 2001.

25. Dhara VR, Dhara R. The union carbide disaster in Bhopal: A review of health effects. Arch Environ Health. 2002;57:391-404.

26. Hogstedt C, Wegman DH, Kjellstrom T. The consequences of economic globalization on working conditions, labour relations and workers' health. In: Kawachi I, Wamala S, eds. Globalization and Public Health. New York: Oxford University Press; 2007:138-157.

27. Kjellstrom T, Lodh M, McMichael T, Ranmuthugala G, Shrestha R, Kingsland S. Air and water pollution: Burden and strategies for control. In: Jamison et al., eds. Disease Control Priorities in Developing Countries, 2nd Edition. New York: Oxford University Press; 2006:817-832.

28. Ostro B. Outdoor Air Pollution. WHO Environmental Burden of Disease Series No 5. Geneva: World Health Organization; 2004. 
29. WHO. World Report on Road Traffic Injury Prevention. Geneva: World Health Organization; 2004.

30. Nantulya VM, Reich MR. Equity dimensions of road traffic injuries in low- and middleincome countries. Inj Control Saf Promot. 2003;10:13-20.

31. Dixon J, Friel S, Omwega AM, Donati K, Burns C, Carlisle R. The health equity dimensions of urban food systems. J Urban Health. 2007 http://dx.doi.org/10.1007/ s11524-007-9176-4.

32. Haughton G, McGranahan G. Urban ecologies. Environ Urban. 2006;18:3-8.

33. IPCC. Climate Change 2001: Mitigation: Contribution of Working Group III to the Third Assessment Report. Cambridge, United Kingdom: Cambridge University Press; 2001.

34. IPCC. Climate Change 2007. Cambridge, United Kingdom: Cambridge University Press; 2007.

35. Campbell-Lendrum D, Corvalan C. Climate change and developing country cities: implications for environmental health and equity. J Urban Health. 2007 http:// dx.doi.org/10.1007/s11524-007-9170-x.

36. McMichael AJ, Githeko A. Human Health. In: McCathy JJ, Canziani OF, Leary NA, Dokken DJ, White KS, eds. Climate Change 2001: Impacts, Adaptation and Vulnerability. Cambridge: Cambridge University Press; 2001:451-485.

37. Aniello C, Morgan K, Busbey A, Newland L. Mapping micro-urban heat islands using Landsat Tm and a Gis. Comput Geotech. 1995;21:965-979.

38. Schar C, Vidale PL, Luthi D, Frei C, Haberli C, Liniger MA, Appenzeller C. The role of increasing temperature variability in European summer heatwaves. Nature. 2004;427:332336.

39. Stott PA, Stone DA, Allen MR. Human contribution to the European heatwave of 2003. Nature. 2004;432:610-614.

40. Kosatsky T. The 2003 European heat waves. Euro Surveill. 2005;10:148-149.

41. Davis RE, Knappenberger PC, Novicoff WM, Michaels PJ. Decadal changes in summer mortality in U.S. cities. Int J Biometeorol. 2003;47:166-175.

42. Hajat S, Armstrong BG, Gouveia N, Wilkinson P. Mortality displacement of heat-related deaths: a comparison of Delhi, Sao Paulo, and London. Epidemiology. 2005;16:613.

43. Gubler DJ, Meltzer M. Impact of dengue/dengue hemorrhagic fever on the developing world. Adv Virus Res. 1999;53:35-70.

44. Knowlton K, Rosenthal JE, Hogrefe C, et al. Assessing ozone-related health impacts under a changing climate. Environ Health Perspect. 2004;112:1557-1563.

45. Patz JA, Campbell-Lendrum D, Holloway T, Foley JA. Impact of regional climate change on human health. Nature. 2005;438:310-317.

46. Dear K, Ranmuthugala G, Kjellstrom T, Skinner C, Hanigan I. Effects of temperature and ozone on daily mortality during the August 2003 heat wave in France. Arch Environ Occup Health. 2005;60:205-214.

47. Dixon J. The Changing Chicken: Chooks, Cooks and Culinary Culture. Sydney: University of New South Wales Press; 2002.

48. Weiss R, McMichael AJ. Social and environmental risk factors in the emergence of infectious diseases. Nat Med Suppl. 2004;10:S70-S76.

49. McMichael T, Bambrick H. Meat consumption trends and health: Casting a wider risk assessment net. Public Health Nutr. 2005;8:341-343.

50. Timmer, P. Food policy in an era of supermarkets: What's different? Electron J Agric Environ Econ. 2004;1:50-67.

51. Hutton G. Considerations in Evaluating the Cost-effectiveness of Environmental Health Interventions. Document WHO/SDE/WSH/00.10. Geneva: World Health Organization; 2000.

52. Hardoy JE, Mitlin D, Satterthwaite D. Environmental Problems in an Urbanizing World. London: Eartscan Publ.; 2004.

53. Hasan A, Patel S, Satterthwaite D. How to meet the Millennium Development Goals (MDGs) in urban areas. Environ Urban. 2005;17:3-19. 
54. WHO. Managing Water in the Home: Accelerated Health Gains from Improved Water Supply. Geneva: World Health Organization; 2002.

55. WHO. Celebrating Water for Life: The International Decade for Action 2005-2015. Geneva: World Health Organization; 2005.

56. WHO and UNICEF. Meeting the MDG Drinking Water and Sanitation Target. The Urban and Rural Challenge of the decade. Geneva: World Health Organization; 2006.

57. Garau P, Sclar ED. Interim Report of the Millennium Project Task Force 8 on Improving the Lives of Slum Dwellers. New York: United Nations; 2004.

58. Ooi GL, Phua KH. Urbanisation and slum formation. J Urban Health. 2007 http:// dx.doi.org/10.1007/s11524-007-9167-5.

59. Tsouros AD, Farrington JL. WHO Healthy Cities Europe: A Compilation of Papers on Progress and Achievements. Copenhagen, Denmark: World Health Organization; 2003.

60. PAHO. Healthy Municipalities, Cities and Communities-Evaluation Recommendations for Policy-makers in the Americas. Washington DC, Pan-American Health Organization, 2005. Accessed at: http://www.paho.org/English/AD/SDE/HS/MC_Recommendations.pdf.

61. Bruce N, Rehfuess EA, Mehta S, Hutton G, Smith KR. Indoor air pollution. In: Jamison DT et al., eds. Disease Control Priorities in Developing Countries, 2nd Edition. New York: Oxford University Press; 2006.

62. Newman P, Kenworthy J. Sustainability and Cities: Overcoming Automobile Dependence. Washington DC: Island Press; 1999.

63. Frumkin H, Frank L, Jackson R. Urban Sprawl and Public Health. Designing, Planning and Building for Healthy Communities. Washington DC: Island Press; 2004.

64. Kjellstrom T, Hinde S. Car culture, transport policy and public health. In: Kawachi I, Wamala S, eds. Globalization and Public Health. New York: Oxford University Press; 2007;81-97.

65. Vukan V. Transportation for Livable Cities. New Brunswick, NJ, USA: Centre for Urban Policy Research; 1999.

66. ILO. Unity Beyond Differences: The Need for an Integrated Labour Inspection System. Geneva: International Labour Office; 2005.

67. OECD. Development Aid at a Glance. Statistics by Region, 2006 Edition. Paris, France: Organization for Economic Cooperation and Development; 2006.

68. Sachs JS. The End of Poverty. How We Can Make it Happen in our Lifetime? London: Penguin Books; 2005.

69. Ul Haq M, Kaul I, Grunberg I. The Tobin Tax. New York: Oxford University Press; 1996.

70. BIS. Triennial Central Bank Survey of Foreign Exchange and Derivatives. Basel, Switzerland: Bank of International Settlements; 2005.

71. United Nations. The Inequality Predicament. Report on the World Social Situation 2005. New York: United Nations; 2005. 